\title{
The Washback of the New Writing Tasks in China's National Matriculation English Test
}

\author{
Chongni $\mathrm{Yu}^{1}$ \\ ${ }^{1}$ School of International Studies, Zhejiang University, Hangzhou, China \\ Correspondence: Chongni Yu, School of International Studies, Zhejiang University, No. 866, Yuhangtang Road, \\ Xihu District, Hangzhou, Zhejiang Province, China.
}

Received: December 3, 2019

Accepted: December 17, 2019 Online Published: December 19, 2019

doi: $10.5539 /$ elt.v13n1p99

URL: https://doi.org/10.5539/elt.v13n1p99

\begin{abstract}
The reform of National College Entrance Examination in Zhejiang Province, China has aroused widespread attention since it was released in 2014. It is notable that new English writing test types were adopted in the English subtest. The continuation task and summary writing become a challenge as well as a promoter for English writing teaching and learning. This study aims to explore the washback effect of the reformed English writing test on the teaching and learning of English writing in high school in Zhejiang, China. Through the method of questionnaire and interview with both teacher and student participants, it was found that the new types of writing test, especially the continuation task, are better at reflecting students' actual English proficiency and improving students' writing and reading ability, compared with the writing tests before the reform. However, the study also demonstrated that some negative effects might be caused due to practical issues. It is expected that this study will shed some light on the teaching and learning of English writing in high school and become a reference for any further educational reforms in Zhejiang and other provinces in China.
\end{abstract}

Keywords: washback, writing test, writing teaching and learning

\section{Introduction}

The National College Entrance Examination is the most important national exam in China. Every year, millions of senior three students take part in this fateful exam, the results of which would decide directly whether they can enter an ideal university or not. As a pilot in the comprehensive reform of college enrollment system, the government of Zhejiang Province in China issued a document in September, 2014 which promoted the reform of the National College Entrance Examination in Zhejiang. In October 2016, the new examination was formally implemented. The enrollment policies, the form, content, as well as the structures of the exam changed evidently. These changes directly and indirectly influence different aspects of teaching and learning in senior high school, which is known as washback effect.

In the "Writing" section of English subtest, namely National Matriculation English Test (NMET), a practical writing, a continuation task and a summary writing task appeared in the exam. In the practical writing, test takers shall write an 80-word essay with the given situation, such as place, aim and time, in the form of outline, graph or table. In the continuation task, test takers shall continue writing for about 150 words after reading a short story of about 350 words with given instructions and key words. As for the summary writing, test takers need to write a summary of 60 words for a 350-word short essay.

These newly-appeared writing test types are a great challenge for students and teachers, because they are totally different from the previous writing tests, and are much more difficult. However, the study on these new kinds of writing types, especially on their washback effect, is still limited.

Therefore, the researcher of this study argues that an empirical research about the washback effect of the writing subtest in the present NMET in Zhejiang Province is needed, because such a research might contribute to the evaluation and improvement of the NMET with a clear clarification of the positive and negative washback effects. Besides, it can promote the teaching and learning of English writing in high school by demonstrating the possible practical problems. The research will also promote the understanding of the mechanism of the washback effect concerning the new writing tasks in the NMET.

The paper is divided into six sections to demonstrate the process of study. The first section presents the 
introduction of background information, the significance and the purpose of the research as well as the layout of the paper. The second section is the review of related literature, specifying the relevant terms, theoretical and empirical researches at home and abroad. The third part demonstrates the methodology of the study. The fourth part is the presentation of the results, in which the outcomes of questionnaires and interviews are clearly illustrated. The fifth section is the discussion of the findings. The sixth part is the conclusion of the study, including the major findings, implications and suggestions for further researches.

\section{Literature Review}

\subsection{Washback Effect}

Washback can be defined as "the effect of testing on teaching and learning" (Hughes, 1989:1), or "the impact of a test on classroom pedagogy, curriculum development, and educational policy" (Pierce, 1992:687) or "an aspect of impact that has been of particular interest to both language testing researchers and practitioners" (Bachman\& Palmer, 1996:30), etc. From the definitions given by different researchers, it can be learned that washback is an effect that comes from tests, and influences various aspects of education.

According to Bachman and Palmer (1996:30), the impact of the test can be observed at two levels, the macro and micro levels, which is illustrated in Figure 1. The macro level includes the impact on society and educational system, while the micro level includes the impact on the individuals who are affected by the test, including test takers, teachers and decision makers. However, how tests affect society, education system and individuals are not explained clearly.

Alderson and Wall (1993:120-121) also try to explore which aspects of teaching and learning tests will exert influence on. They put forward "Washback Hypotheses", which are 15 possible hypotheses regarding washback. Their hypotheses focus on the teaching, including the aspects of content, method, attitudes, as well as learning, including content, attitudes, degree and depth. What's more, the strength of washback is assumed to relate to the importance of the test and the characteristics of individuals.

Hughes (qtd. in Bailey, 1996:262)'s mechanism of washback links all aspects in washback. He writes: "In order to clarify our thinking on washback, it is helpful, I believe, to distinguish between participants, process and product in teaching and learning, recognizing that all three may be affected by the nature of a test." The participants include students, teachers, administrators, materials developers and publishers. The processes mean "any actions taken by the participant which may contribute to the process of learning" and product refers to "what is learned (facts, skills, etc.) and the quality of the learning (fluency, etc.)". Based on previous studies, Bailey (1996:264) proposes a model of washback (Figure 2). The participants and products are placed in the boxes while the process is presented in arrow form. In this way, every aspect of washback effect is clearly demonstrated.

\subsection{English Writing Tasks}

\subsubsection{Practical Writing}

Literally, practical writing is the writing for practical issues in life, study and work. Su, Wang and Xiao (2011), editors of a book about practical writing teaching argue that practical writing is the most widely used way of communication except talking, in modern society. The ability to write practical essays prepares students to compete in an international environment. Therefore, the test of practical writings in national English exams, such as the NMET, is necessary and meaningful.

\subsubsection{Continuation Task}

The concept of Continuation task is put forward by professor Wang Chuming (2012), who defines the Continuation task as "a new teaching method that integrates imitation with creativity and combines learning with using in writing communication" (2). As the name suggests, in a continuation task, students are required to continue writing, based on a piece of short story. According to Swain and Lapkin (1998), language learning happens when language learners are able to use the language of others. The Continuation task links the language input and output to promote language learning, which is the most evident strength argued by Wang (2012). 


\begin{tabular}{|l|l|l|}
\hline \multirow{2}{*}{$\begin{array}{l}\text { Test taking and } \\
\text { use of test scores }\end{array}$} & Impact & $\begin{array}{l}\text { Macro: Society, } \\
\text { education system } \\
\text { Micro: Individuals }\end{array}$ \\
\cline { 2 - 2 }
\end{tabular}

Figure 1. The Impact of Washback

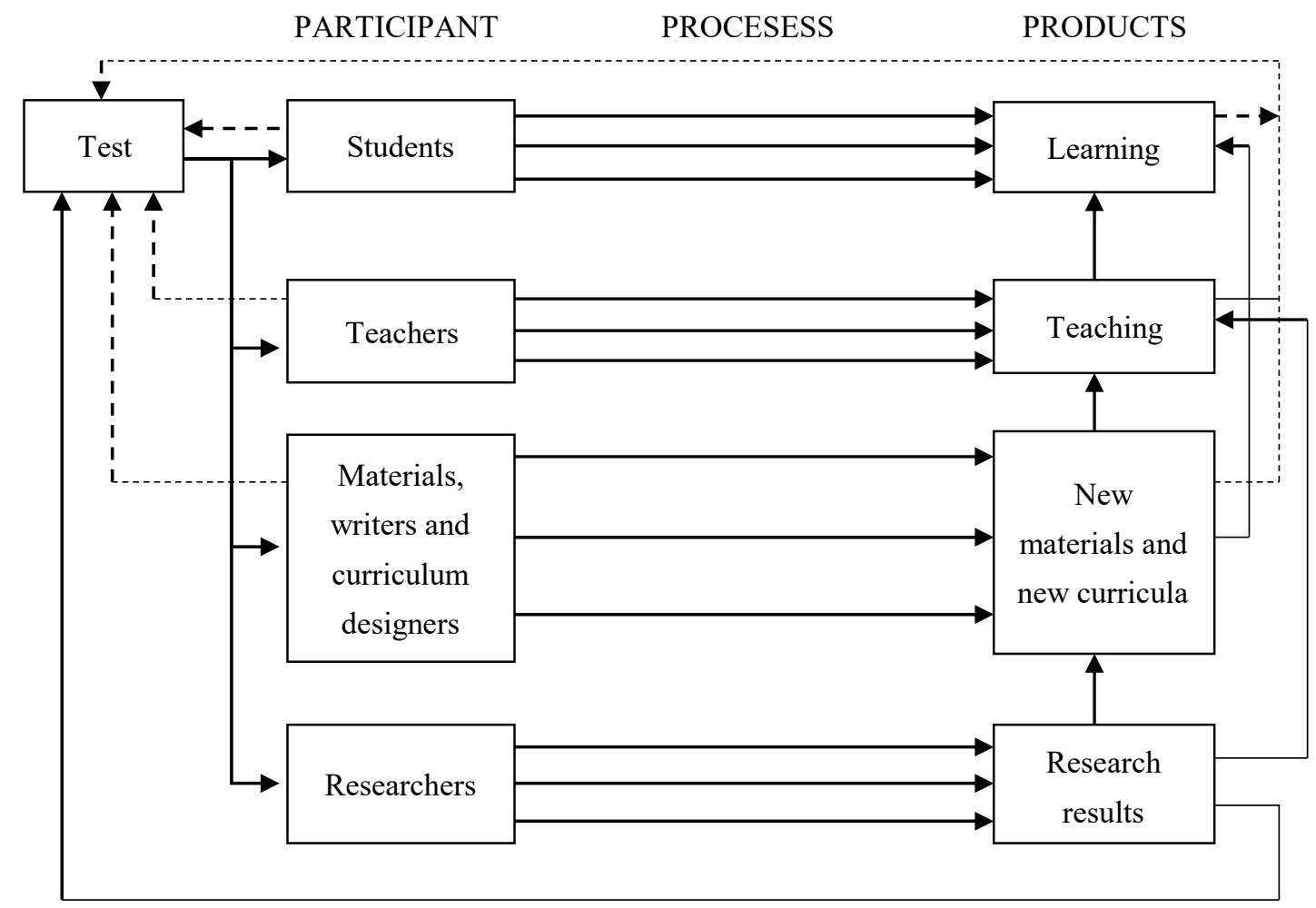

Figure 2. A Model of Washback Effect

\subsubsection{Summary Writing}

A summary is the main idea of something in a concise form. Three features are emphasized by Fan and Jia (2017:46). Firstly, "objectivity", which means that no personal opinions or judgment should be involved. Secondly, "conciseness", which is to simplify the original text. The third is "coherence", meaning all points should form a united whole.

Yao (2017) states that the training and testing of summary writing improve students' ability to acquire and process information, which lays a good foundation for further studies and work. Like the continuation task, the summary writing is also based on the language input. Thus, summary writing, a combination of language input and output, is believed to promote second language learning.

\subsection{Washback of English Writing Test}

Researchers were interested to investigate the washback of English writing tasks in various English examinations. For example, Estaji and Tajeddin (2012) investigated the washback effect of the IELTS academic writing test on English learners. They aimed to figure out whether this test would influence learners' motivation, test-taking anxiety, test-taking strategies as well as the expectations students bring to their courses. Although the test affected learning, and learners can profit from it in terms of raised writing scores, owing to more attention paid to the IELTS preparation tasks, the influence of the writing test on other English capabilities of learners were surprisingly limited.

In the following year, Estaji (2013) then refined the study to illustrate the complex washback effect of IELTS academic writing on learners. Still, he found that the IELTS tests and preparation courses, powerful as they are, cannot lead to profound changes in learners' perspective.

The washback of high-stake writing test is also observed by domestic researchers in China. Qi (2007)'s empirical 
research about the washback of writing test in the NMET of Guangdong Province, China, showed that the tests' communicative purpose was not observed in class. Both teachers and students focused on the assumed preferences of the markers, such as clean handwriting and correct grammar, but the communicative context of the writing was neglected.

The empirical researches of the washback of a specific type of writing task, deserve equal attention. Through an empirical study towards vocational school students, Fan (2016) found that recitation and imitation could significantly improve students' English practical writing proficiency. McDonough, Crawford and Vleeschauwer (2016) conducted a study in a Thai EFL university and found adequate summary writing instruction can improve students' summary writing ability, especially textual appropriation.

The previous studies present the basic concepts and relevant studies about writing testing and washback and lay a solid foundation for the present research about the washback effect of the writing test in new NMET of Zhejiang, China. However, the study of the washback of a specific writing test type, for example, the continuation task, is still inadequate. Therefore, more empirical researches should be conducted to demonstrate the washback of writing tests, especially the writing test in the reformed NMET in Zhejiang, China.

\section{Method}

\subsection{Research Questions}

Based on the prior theoretical and empirical researches, this study tries to explore the washback of the new writing tests of the reformed NMET in Zhejiang Province. In other words, the study aims to figure out the influence of the new English writing tests on the teaching and learning of English writing in high school. The research questions are as follows:

1) Does the reformed NMET in Zhejiang, China, especially the writing test, exert any washback effect on teaching and learning in high school?

2) If so, is the washback positive or negative?

3) How does the reformed NMET affect teaching and learning in high school?

4) What are the reasons for the appearances of these washback effects, especially the negative ones?

\subsection{Participants}

The sample of this study is the high school teachers and students in Zhejiang, China and students who took part in the NMET in Zhejiang in 2017. Therefore, the participants were expected to vary in terms of the locations and school levels. The teachers and students who participated in the study were mainly from five schools in three cities in Zhejiang, China. Some freshmen from a key university in Zhejiang, China, were also selected randomly as participants for this study, because they were the first to take part in the reformed NMET in Zhejiang.

\subsection{Instruments}

The questionnaires were designed respectively for teachers and students in Chinese, based on relevant questionnaires in other researchers' studies, such as the questionnaires by Qi (2004), Hao (2012).

The questionnaire for teachers covered basic individual information, views on English writing teaching, the teaching practices before and after the reform and the strategies used for different types of English writing. Targeted at both high school students and freshmen in university, the questionnaire for students consisted of 14 items, such as basic individual information, views on English writing learning, attitudes towards different types of writing, important qualities required in different writing tasks. It was worth noting that the questionnaires for high school students and for freshmen were collected and analyzed separately because they were viewed as two kinds of participants.

The interviews were semi-structured, one-to-one, face-to-face and conducted in the teacher's office. The records were kept intact in the whole process of interviews. The basic questions of the interviews were decided in advance, while further questions were raised according to their answers to the basic questions.

The data was collected both online and offline from 12th March to 23rd March, 2018. 238 copies of student questionnaire were collected, 40 online, 198 offline and 50 copies of teacher questionnaire were collected in total, 29 online, 21 offline. As for the interview, four teachers and seven students in the above-mentioned high schools were interviewed. 


\section{Results}

\subsection{Questionnaires}

\subsubsection{Questionnaires for Teachers}

50 copies of teacher questionnaires were collected and 45 copies were valid in total.

Firstly, the participants were asked about the time spent on English writing teaching. The results in Figure 3 show that as students entered a higher grade and got closer to the date of NMET, teachers would spend more time on English writing teaching.

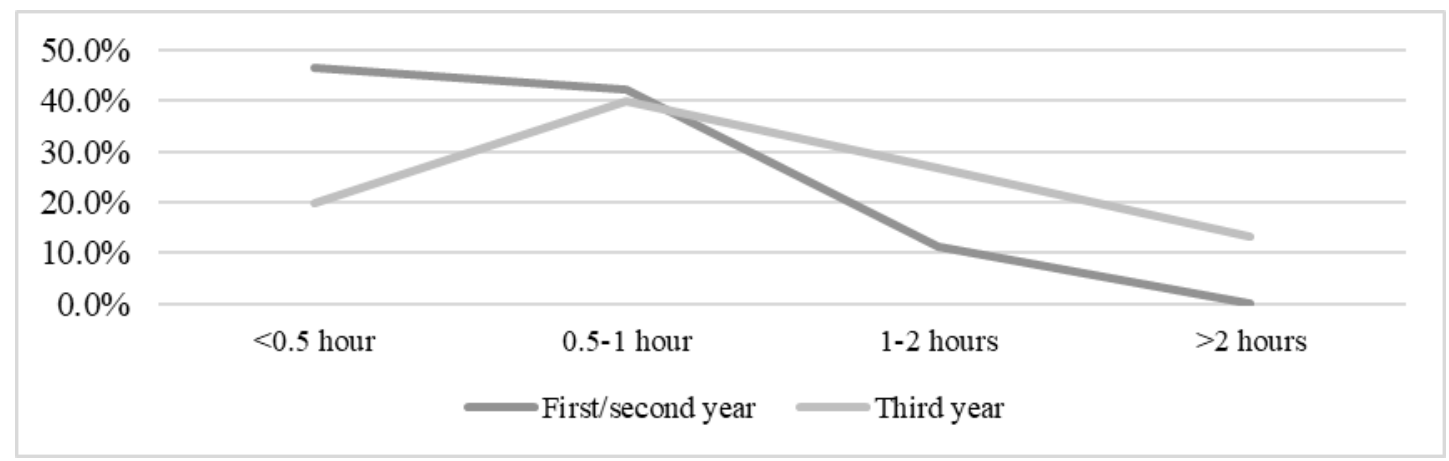

Figure 3. Time Spent on English Writing Teaching

As for the view point on different types of English writing, the answers vary. Participants were required to choose the type of writing that can best reflect the actual language proficiency of their students as well as the type of writing which is the best at promoting students' English writing learning. From Figure 4, we can see that the writing types adopted after the reform, namely the continuation task and the summary writing were regarded as better types of writing, compared with writing with a given topic, or writing with a given outline. Among all the types of writing, the continuation task gained the most popularity, which suggested that it might be a better choice for the evaluation and improvement of students' English proficiency.

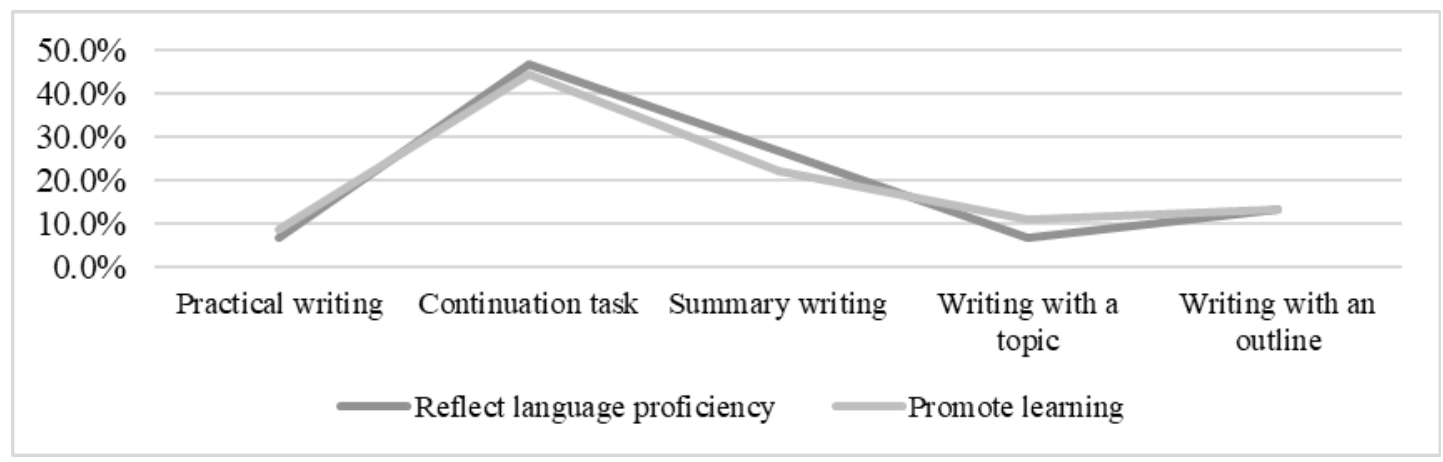

Figure 4. Attitude Towards Different Types of Writing

In the following part of the questionnaire, the washback was examined in terms of teaching method and focuses of teaching. To examine the influence of reform on teaching method, participants were required to choose the corresponding frequency of using various method before and after the reform. The four options (never, seldom, sometimes, always) were given values of 1, 2, 3 and 4 . A weighted average was calculated to demonstrate more clearly the change of teaching methods. From Figure 5, we can see that evident washback occurred in some less frequently used teaching methods, such as group discussion and writing in and after class. On the contrary, teaching methods that were frequently used before, like explaining writing requirements and analyzing writing problems, were not evidently influenced. This result is quite different from the research of the washback of Hong Kong Certificate of Education Examination by Cheng (1997), who found that the methodology that teachers employed seldom change with the implementation of the exam. 


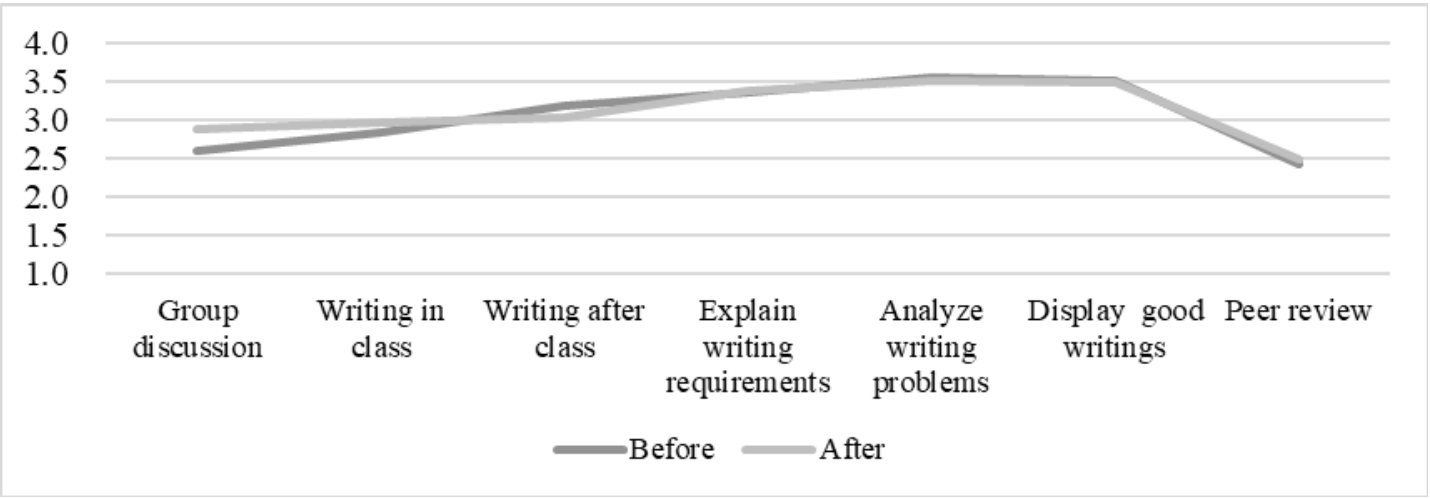

Figure 5. Teaching Methods Adopted Before \& After the Reform

The teacher participants were then required to recall how often they paid attention to different aspects of writing, including the variety of vocabulary and sentence structure, grammar, cohesion, logic, native expression, relevance to the topic, content integrity and originality. Again, the four options of "never", "seldom", "sometimes" and "always" were assigned values of 1,2,3 and 4 to calculate the weighted average. As is presented in Figure 6, the participants were more concerned about almost all the above-mentioned aspects of English writing after the application of new types of writing task in the NMET.

The last part of the teacher questionnaire was about teachers' view on the most important approaches for students to improve English writing. The participants were asked to choose four approaches that they thought were effective before and after the reform. From Figure 7, we can see that exam-oriented approaches such as memorizing model essays of exams, memorizing classic sentences and articles and doing massive writing exercises were less preferred after the reform. On the contrary, competence-oriented approaches such as logic training, requirement analysis training, lexical and syntactic training and the training on the essay structure, were regarded as more useful methods to improve students' English writing ability.

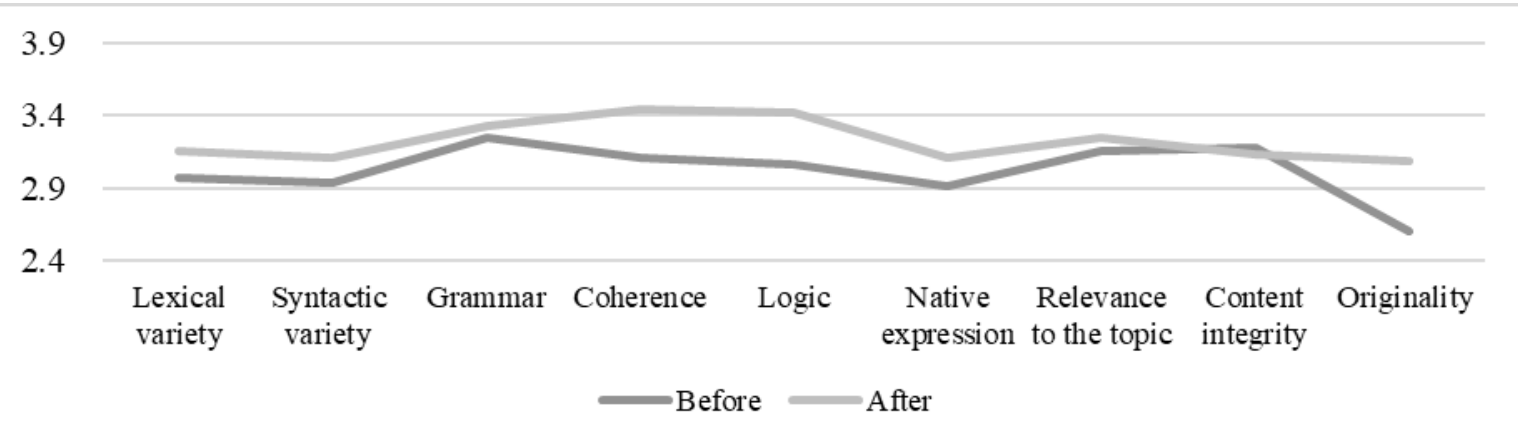

Figure 6. Focus Before\& After the Reform

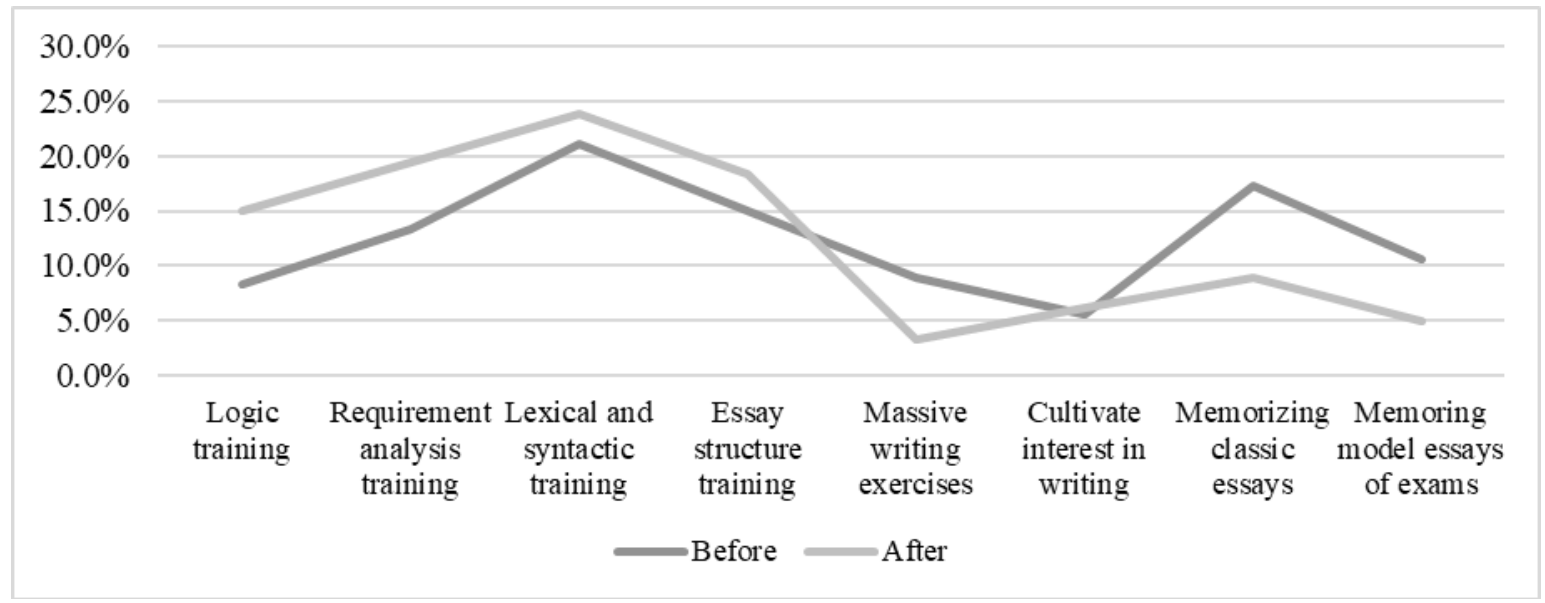

Figure 7. Effective Approaches to Improve Students' Writing 


\subsubsection{Questionnaires for Students}

238 copies of student questionnaires were collected totally and 222 copies were valid. Among them, 112 were males and 110 were females. 55 were freshmen in university and 167 were high school students. 188 were from key high schools while 34 were from ordinary schools.

The analysis of the answers of university students and high school students illustrates that there is no evident difference between these two groups of participants as far as this study is concerned. However, student participants from key schools and ordinary schools show some difference in several items of the questionnaires.

Like the teacher participants did, the students were asked about their basic situation of English writing learning. As is presented in Figure 8, most of the students from key and ordinary schools viewed "improving English communicative ability" as the ultimate purpose of learning English writing and another large proportion of students thought "gaining high scores in NMET" was their goal for learning English writing. A certain proportion of students from ordinary high school were not clear about their aim of learning English writing.

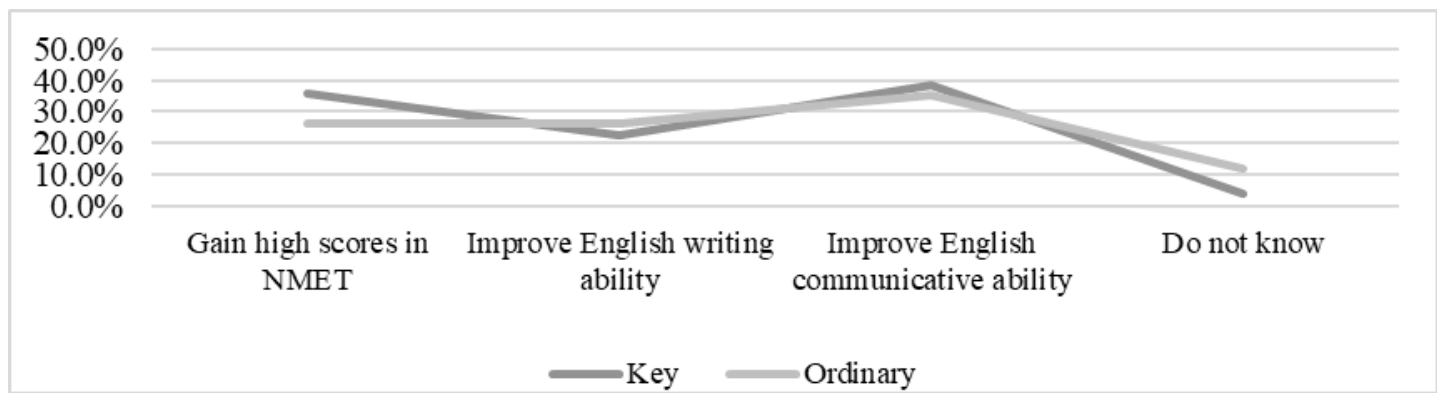

Figure 8. Goal of Learning English Writing

Then student participants were required to select the type of writing that was the best at reflecting their actual language proficiency and the type of writing that was easier to write. The results presented in Figure 9 and Figure 10 indicated that most participants thought the continuation task can best reflect their actual English proficiency, while it was not easy to write. The result was quite similar regarding both students from key schools and ordinary schools. Another proportion of students chose practical writing as the best reflection of their English writing ability and a larger proportion viewed it as an easier writing task.

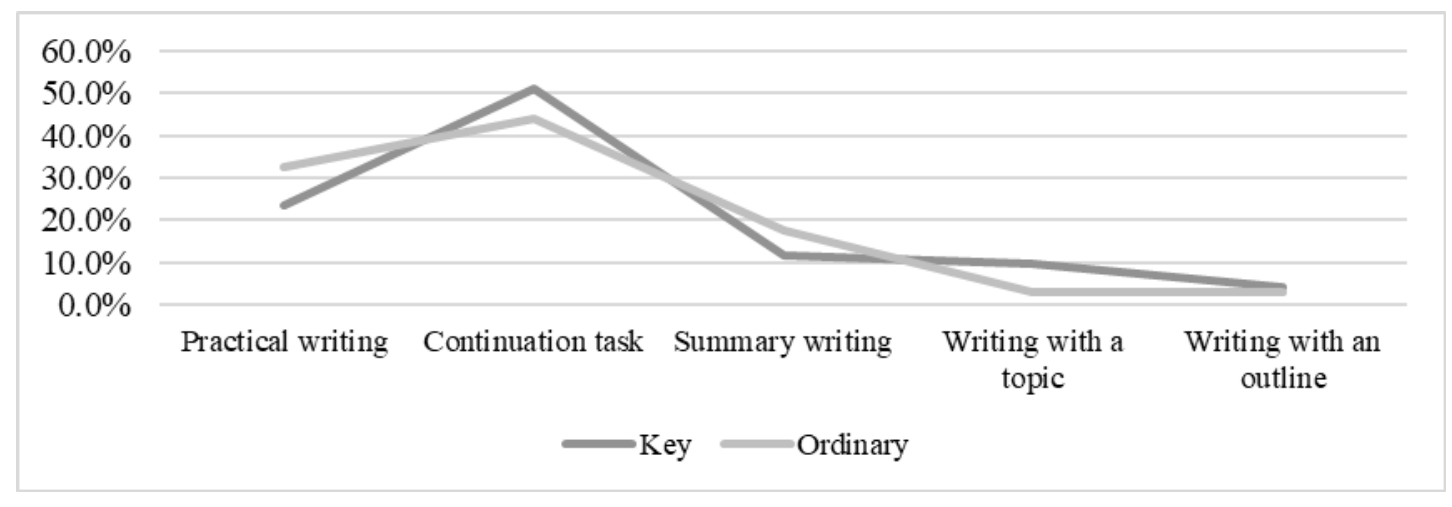

Figure 9. Writing Task That Best Reflects Students' Writing Proficiency 


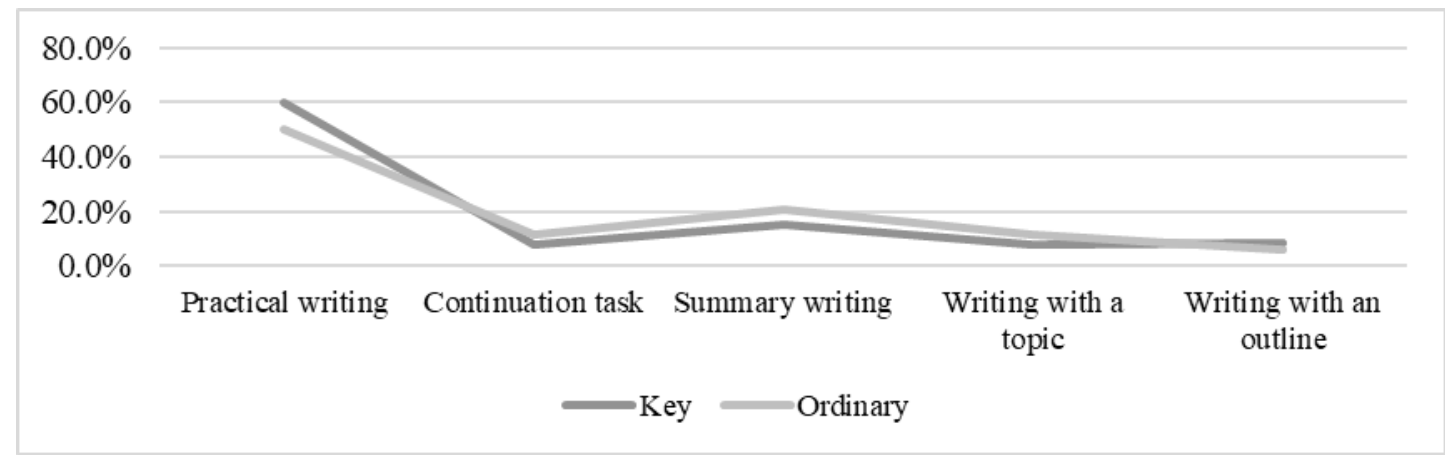

Figure 10. Writing Task That Is Easiest to Write

Finally, student participants needed to select the four most important qualities needed when writing practical essays, continuation tasks and summary articles. From Figure 11, we can see that competence-related qualities such as logic thinking, requirement analysis ability, basic lexical and syntactic proficiency, overall organization of the article were regarded as the most significant factors for all three types of writing task, while exam-oriented factors, namely massive exercise, memorizing classic sentences and model essays of the exam were less important in students' eyes.

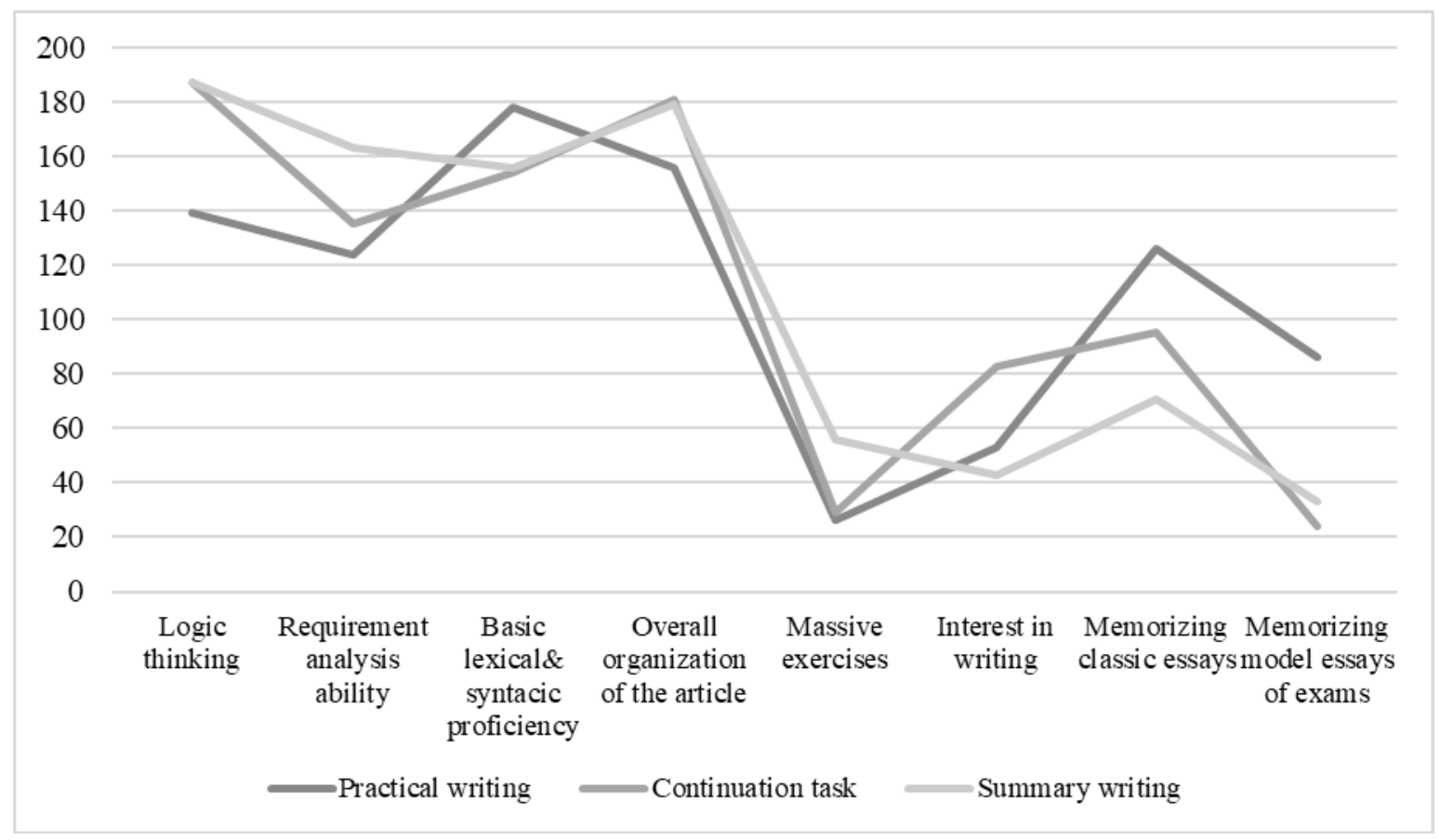

Figure 11. Important Qualities Required in Three Types of Writing

\subsection{Interviews}

Four teachers and seven students from five high schools were interviewed for the study. The interviews were all made in Chinese and then translated into English.

\subsubsection{General Views Towards Three Types of Writing}

In regard of the newly applied types of writing, some similar views by both teachers and students in both key and ordinary high schools can be summarized. Practical writing is regarded to be much easier than the continuation task and summary writing, because it owns set patterns, such as fixed format, frequently-used expressions and various model compositions. The results gained from questionnaires were the same. Memorizing these set patterns would largely raise students' grades in the exam. For example, Student A from a key high school said,

The practical writings have a lot of set patterns..... I like it because I can get higher marks compared with the other two types..... We need to write at least one composition every week and memorize the sample writings given by our English teacher. Then she will require us to write them down from memory. 
On the contrary, the continuation task and the summary writing were thought to have less set patterns. To gain a satisfactory result in doing continuation task, good reading ability, cohesion, coherence, language ability and logical sense are all essential. Memorizing model essays is no longer helpful. Just like Teacher A from the same school said,

Students have to understand the story first, and then continue the story based on two beginning sentences given below. Besides, the cohesion of two paragraphs is very important and is a great challenge for students...... Some stories have a strong logic, and cohesion is thus quite demanding. Students have to write on the basis of one storyline......Apart from reading and cohesion capacity, students also need to tell stories, so imagination is significant, too.

As for the summary writing, the reading capacity as well as the summary capacity are examined, since students need to write a short summary after reading a long passage, as Teacher B, an experienced and aged English teacher from a famous key high school said,

As for the summary writing, firstly students should pay attention to the reading skills and find the topic sentence, right? Another point is the information extraction...... Then, there is the sentence pattern transformation and lexical variation......

Almost all teacher interviewees said the writing trainings aiming at the continuation task and the summary writing had improved students' writing ability evidently. For example, Teacher D from a key high school said,

Students are better at English writing and the overall English proficiency is improved, compared with my students who took the NMET before the reform.

The opinions held by student and teacher interviewees were similar to the empirical study by Li (2017), which demonstrated that the continuation task raised students' complexity, accuracy and fluency of English writing.

\subsubsection{Existing Problems}

However, some practical factors, such as the inexperience of teachers, will devalue the reform. Many teachers, especially the young teachers without enough teaching experience in ordinary high schools, found it quite challenging to prepare students for the writing tests.

Teacher C, a young female English teacher in an ordinary high school admitted that the reform was a big challenge, not only for students, but also for herself, because she had never taught this kind of writing before. She said,

Actually, I didn't know how to write, either. I was confused when I was teaching the first group of students after the reform plan was carried out. Now it's much better for me, because both my students and me have some experience.

Owing to subjective factors like the inexperience of teachers when facing a totally new type of writing test, some misleading teaching phenomenon might exist. Some students in a less prominent key high school complained that their English teacher always relied on the model essays of the writing test, which limited their imagination to some extent. Student B commented on this topic,

I feel when there is a model essay, the teacher will read it first and have a bias when reading our writings...... She always analyzes the writing test according to the sample essays of the test......At least it won't be wrong.

The same situation exists when it comes to summary writing. Student B continued his comment and said,

In the last model exam, the summary writing is about Greenland. The essay mentioned that the ice of Greenland takes up $10 \%$ of the water storage on earth. Our teacher stressed this was a key point, but she mentioned before that in summary writing, numbers can be ignored. It's contradictory.

After hearing the confusion of the student, the researcher asked Teacher B about this issue. He was surprised and answered that he did not pay much attention to the sample essays of writing tests and exercises. On the contrary, he encouraged his students to share their own ideas and have some discussion about different story endings.

\subsubsection{Exam-oriented Teaching}

Then how are students taught English writing in high school after the reform? Surprisingly, most teachers interviewed focus on the basic language training during the first year. In the second and third year, they would train their students to practice continuation task and summary writing. When the exams are approaching, teachers would assign a lot of writing exercises for students. This is similar in both key high schools and ordinary high schools. Teacher A said that when her students were in the first year, she would teach with a focus 
on language knowledge, such as grammar, vocabulary. But starting from the second year, she would teach with a focus on the continuation task and summary writing. Similarly, Teacher C from an ordinary school agreed. In her school, first-grade students would be trained on vocabulary and syntax, while the second-grade and third-grade students got more targeted training towards the continuation task and summary writing. But Teacher D said that in her school, students got some training on the continuation task during the first year, and summary writing in the second year. Still, the focus of teaching is on the basic language foundation during students' first year in high school.

Although more targeted training appears during students' second and third school year, less targeted and purposeful practices are available throughout the whole three years. That is to say, the reform of the writing test exerts influence on the teaching and learning of English writing or even other parts of English teaching.

To prepare students for the continuation task and summary writing of the NMET, English teachers would adopt some skill-oriented approaches. Teacher A said,

During students' first year, when I taught them the long essays in the textbook, I would ask them to find out the topic sentence of the text. I was preparing them for the summary writing practices in the future.

To improve students' overall writing ability, Teacher C let her students read English more. She said,

Since the continuation task is always narrative essays, I will guide students to read some narrations and even English novels and let them pay attention to the description of details and emotions. I hope they can use some native and classic expressions they remember when doing the continuation task later.

However, compared with these two types of writing, less attention is paid to the practical writing because it is easier. Clearly, the continuation task and the summary writing exert more influence on the teaching and learning of English writing. In this process, positive washback is expected by the reformers and test designers. However, some practical factors such the inexperience of teachers and the marking procedures might cause unexpected negative effects. The detailed positive and negative washback effects along with their causes will be discussed in the following part.

\section{Discussion}

\subsection{Mechanism of Washback}

The analysis of both teacher and student questionnaires and interviews demonstrates the washback effects of the writing test in the reformed NMET in Zhejiang, China. The results of questionnaires show that more efforts are devoted to English writing teaching and learning. Besides, both teachers and students thought competence-related qualities far outweigh the exam-oriented ones after the reform. The reference books adopted and teaching time on English writing also changed evidently. Meanwhile, the continuation task was regarded as better flection of students' actual English writing proficiency and can promote writing.

Referring to Hughes (qtd. in Bailey, 1996:262)'s mechanism of washback, the participants, processes and the products are thus clarified. As far as the washback is concerned, the participants are mainly teachers and students in high school in Zhejiang Province. The process of the washback is that the continuation task and summary writing evaluate students' ability of reading, cohesion, coherence, creative thinking, logic thinking, linguistic knowledge, summarizing, etc., thus teachers and students pay more attention to the teaching and learning of these capabilities so that students can get high marks in exams. More time and efforts are devoted to English writing learning and teaching. As a result, the change of teaching focus, method and increase of teaching time, as well as the change of learning focus and targeted training lead to students' overall improvement in English writing. The details are presented in Figure 12. 


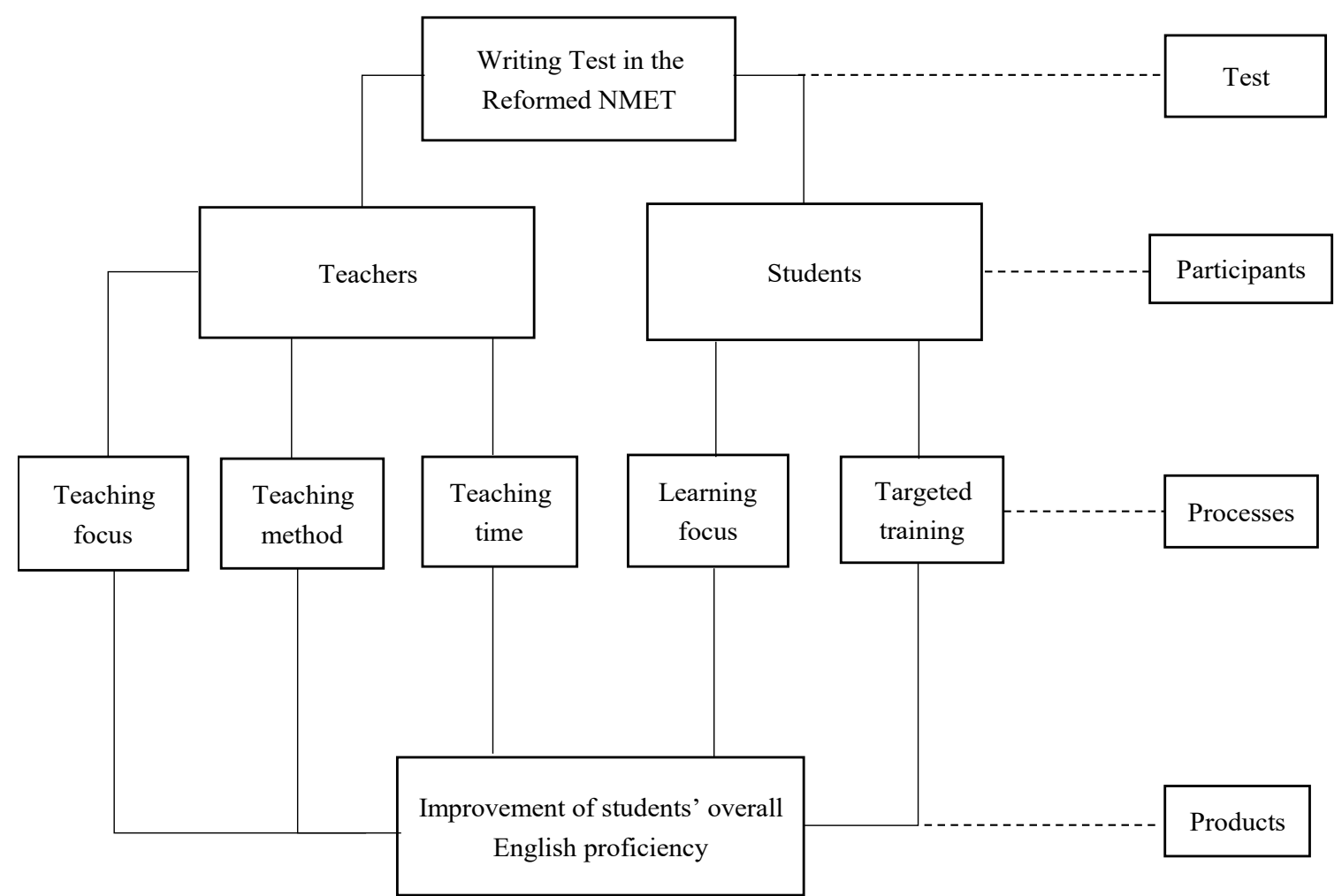

Figure 12. Mechanism of Washback of the New Writing Tasks in the NMET

\subsection{A Comparison of What Is Taught and What Is Tested}

The results of the questionnaire and interview demonstrate the viewpoint held by high school English teachers and students towards the reformed English writing test of NMET as well as the teaching and learning practices targeted at English writing. Less attention is paid to the practical writing by both teachers and students, because it is much easier compared with the other two kinds of writing test.

More efforts are devoted to the continuation task as well as the summary writing. These two types of writing are viewed to be quite challenging by both teachers and students. Through the investigation, the researcher found that the reading ability, cohesion, coherence, language skills, logic and imagination were thought to be essential in doing the continuation task. The result coincides with the requirements listed in Understanding the Test Explanation (Xue, 2017:5):

1) Cohesion with the listed short essay and the first sentence provided;

2) Richness of the content and the coverage of the listed key words;

3) Richness and accuracy of syntactic structure and vocabulary;

4) Coherence of context.

The second point "richness of the content" is similar to the imagination and logic mentioned by teacher participants, while the third point "richness and accuracy of syntactic structure and vocabulary" corresponds with the language skills. In order to prepare students for the continuation task, teachers would increase students' reading training and encourage students to read English novels. Students would also pay attention to the descriptions of details while reading. As a result, the students' language proficiency level is raised because of the reformed writing test.

As for the summary writing, the ability of reading and summarizing are thought to be important. In the Understanding the Test Explanation (Xue, 2017:5), the requirements for summary writing were listed:

1) Understanding and presentation of the key points of the text;

2) Accuracy of the syntactic structure and vocabulary;

3) Coherence of context;

4) Independence of the expression of the key points. 
Clearly, some of the requirements were ignored by the teachers and students. Coherence, an essential requirement in both continuation task and summary writing, was seldom mentioned when asked about the summary writing in the interview and the questionnaire. So did the fourth point. Still, to prepare students for the summary writing, some teachers would require their students to pay attention to the topic sentence and the structure of the text while reading, which is helpful to raise students' general English proficiency, especially the reading skills.

\subsection{Reasons for Positive and Negative Washback Effects}

Owing to two characteristics of the NMET, namely its high stakes and its function as a model for teaching and learning (Qi, 2004), the NMET plays an influential role in shaping teaching and learning in high school. Therefore, the reformed writing part of Zhejiang NMET is expected to promote the teaching and learning of English writing. It is also what teachers, students and the researcher of this study have observed.

But overall, the continuation is better at reflecting students' actual language proficiency and promoting learning, according to the results of questionnaire and interview. It corresponds with the study of Wang (2012), who argues that the continuation task links the language input and output, as well as promotes the creative thinking of students, and thus promotes English learning.

The summary writing is also beneficiary for students' English learning. The purposeful reading of English essays, the analysis and summarization after reading, as well as the consideration of cohesion and coherence, are essential in summary writing, and useful in more general writings. Therefore, the newly adopted writing tasks in NMET in Zhejiang, namely the continuation task and summary writing, can exert beneficial washback effects to the teaching and learning on English writing.

However, some practical issues can cause negative effects. From the interviews with students and teachers, we can see that the inexperience of teachers, especially in some ordinary high schools, might weaken the positive washback intended by test designers. For example, some young teachers tend to rely on the sample essays of the test which might hinder the intended positive washback. But these negative effects are expected to diminish as new English teachers gain more experience on teaching these forms of writing. Indeed, the results coincide with the study of new "O-level" exam by Wall and Alderson (1993) which is mentioned before. Their empirical study found that the content of teaching and ways of assessing were influenced both positively and negatively.

\section{Conclusion}

Through the investigation in the form of both teacher and student questionnaire and interview, it was found that the writing test of the reformed NMET exerted some washback effect on the teaching and learning of English writing in high school. The washback can vary from school to school, from teacher to teacher, from student to student. Overall it exerted positive influence on the teaching and learning, and thus improved students' general language ability.

What's more, different washback effects were related to different types of writing. The practical writing promoted students' practical writing ability and the summary writing task was beneficial for student's reading and summarizing abilities. As for the continuation task, it was believed to improve students' ability of reading, cohesion, coherence, creative thinking, logic thinking.

However, some unexpected negative effects were observed due to practical factors. The inexperience of young teachers when facing new writing task sometimes would cause unexpected negative effects and thus weaken the positive washback.

It is hoped that this study can shed some light on the teaching of English writing in high school. The reform of NMET in Zhejiang, China, especially the writing section, releases a message that more emphasis should be laid on the teaching of quality-oriented capability, rather than exam-oriented skills that teachers and students prefer, like memorizing model answers, memorizing fixed formats and massive exercises. Following the reformed NMET, the focus of teaching is shifting to the improvement of students' overall English proficiency.

Besides, the study verifies the positive effects brought by the continuation task that Wang (2012) had put forward, and contributes to the improvement of this writing task and the application of continuation task in English teaching and learning.

Further researches can be conducted to figure out the washback of other sections of the NMET, such as the Reading Comprehension task. Since certain washback effects might not have appeared, more studies could also be conducted years later to illustrate any change and appearance of washback in the long run. 


\section{References}

Alderson, J. C., \& Hamp-Lyons, L. (2016). TOEFL preparation courses: a study of washback. Language Testing, 13(3), 280-297. https://doi.org/10.1177/026553229601300304

Alderson, J. C., \& Wall, D. (1993). Does washback exist? Applied Linguistics, 14(2), $115-129$. https://doi.org/10.1093/applin/14.2.115

Bachman, L. F., \& Palmer, A. S. (1996). Language testing in practice. Oxford, England: Oxford University Press. https://doi.org/10.2307/328718

Bailey, M. K. (1996). Working for washback: a review of the washback concept in language testing. Language Testing, 13(3), 257-279. https://doi.org/10.1177/026553229601300303

Cheng, L. (1997). How does washback influence teaching? Implications for Hong Kong. Language \& Education, 11(1), 262-267. https://doi.org/10.1080/09500789708666717

Estaji, M. (2012). Demystifying the complexity of washback on learners in the IELTS academic writing test. Studies in English Language Teaching, 1(1), 211-226. https://doi.org/10.22158/selt.v1n1p211

Estaji, M., \& Tajeddin, Z. (2012). The learner factor in washback context: an empirical study investigating the washback of the IELTS academic writing test. Language Testing in Asia, 2(1), 1-21. https://doi.org/10.1186/2229-0443-2-1-5

Fan, L., \& Jia, G. (2017). Stratgey for English summary writing. Zhejiang Examination, 3, 46-49.

Fan, P. (2016). An empirical study on the effect of recitation-imitation upon the vocational school students' English practical writing proficiency (Unpublished master's thesis). Northwest Normal University, Lanzhou, China.

Hao, M. (2012). The shift of reading comprehension items in NMET of Shanghai and its backwash on high school English reading teaching (Unpublished master's thesis). East China Normal University, Shanghai, China.

Hughes, A. (1989). Testing for language teachers. Cambridge, England: Cambridge University Press. https://doi.org/10.2307/327632

McDonough, K, Crawford, W. J., \& Vleeschauwer, J. D. (2014). Summary writing in a Thai EFL university context. Journal of Second Language Writing, 24(1), 20-32. https://doi.org/10.1016/j.jslw.2014.03.001

Pierce, B. N. (1992). Demystifying the TOEFL reading test. TESOL Quarterly, 26(4), 665-691. https://doi.org/10.2307/3586868

Qi, L. (2004). The intended washback effect of the National Matriculation English Test in China: Intentions and reality. Beijing, China: Foreign Language Teaching and Research Press.

Qi, L. (2007). Is testing an efficient agent for pedagogical change? Examining the intended washback of the writing task in a high-stakes English test in China. Assessment in Education Principles Policy \& Practice, 14(1), 51-74. https://doi.org/10.1080/09695940701272856

Su, W., Wang, Z., \& Xiao, W. (2011). Practical English Writing. Gansu, China: Gansu Nationality Press.

Swain, M., \& Lapkin, S. (1998). Interaction and second language learning: Two adolescent French immersion students working together. The Modern Language Journal, 3, 320-327. https://doi.org/10.1111/j.1540-4781.1998.tb01209.x

Wang, C. (2012). Continuation task: An effective method to promote foreign language learning. Foreign Language World, 5, 2-7.

Xue, J. (2017). Understanding the Test Explanation. Beijing, China: Modern Education Press.

Yao, B. (2017). Preparation and strategy for English summary writing. Zhejiang Examination, 10, 45-49.

\section{Copyrights}

Copyright for this article is retained by the author(s), with first publication rights granted to the journal.

This is an open-access article distributed under the terms and conditions of the Creative Commons Attribution license (http://creativecommons.org/licenses/by/3.0/). 